\title{
The Phenomenon of Culture Shock on Western People in Senggigi, West Lombok
}

\author{
Atmy Rese \\ Mataram University \\ Mataram, Indonesia \\ atnyrese@gmail.com
}

\begin{abstract}
This study aims: (1) To describe the underlying cause of culture shock on western people in Senggigi (2) To describe the impact of culture shock on western people in Senggigi. This research is a research using descriptive qualitative approach. Source of data obtained through words and actions, written sources and photographs. Data collection techniques used in this study are interviews, observation and documentation. Subjects in this study were eight informants. It consists of two westerners from Germany, one from Italy, three from Australia, one from England and one from Switzerland. These foreign citizens have been living in Lombok for more than ten years on average. Informant selection technique used is purposive sampling technique. The technique of data validity using source triangulation techniques. Data analysis techniques use interactive analysis model consisting of data collection, data reduction, data presentation, and conclusion. The results of this study indicate that the underlying cause of culture shock in western people in Senggigi is divided into internal and external causes. Culture shock that occurs in each individual has symptoms and reactions in the form of mental and physical stress different about the extent to which culture shock affects his life. The experience of normal culture shock occurs in overseas students who start their lives in new areas with different cultural situations and conditions from their home regions. Four phases in culture shock are optimistic phase (first phase), cultural problem (second phase), recovery phase (third phase) and adjustment phase (last phase). The impact of culture shock on western people in Senggigi is in the last phase in culture shock which is indicated by the cultural adaptation that applied by western people in Senggigi as a place of monitoring.
\end{abstract}

Keywords- Western people, Culture Shock, Cultural Adaptation.

\section{INTRODUCTION}

Most tourism palaces are identical with western or foreign people. In Lombok there are many beautiful sight, one of them is the Senggigi Village. The tourist sites spread across several places on the island of Lombok especially in Senggigi brings many business opportunities for both local people and for foreign citizens who are interested in opening business opportunities on the island of Lombok. Not a few foreign nationals who choose to settle and open a business on the island of Lombok. Not even a few of them also choose to marry the people from its local community. It can cause cultural changes caused by the high level of social geographic movement by an individual or group of individuals above the plurality of cultures, ethnicities, religions, languages, customs and so on Lombok Island, so it is possible that cultural contact between communities local with the foreigner or westerner. Given the diversity of cultures causing cultural differences which exist between one culture with other cultures in the homeland of Indonesia, it is no wonder if the potential for cultural shock among the nomads of individuals living in a new area will also be greater. In that context, in general, cultural shock occurs due to the unpreparedness of individuals facing cultural differences known as culture shock, which is indicated in the early stages of life in the jungle he will experience a problem of discomfort to his new environment which will then affect both physically and emotional as a reaction when moving and living with new environments, especially those that have different cultural conditions. When the new cultural values feel different from the cultural values they have, as a result the individual will surely feel very disturbed by it. The new culture can be potentially stressful, because understanding and accepting other cultural values is not an instant thing and becomes something that can not fully run easily. The concept of culture shock was first introduced by an anthropologist by Oberg (1960) to describe the profound and negative response of depression, frustration, and disorientation experienced by individuals living in a new cultural environment (Dayakisni, 2012: 265).

In this island, now many westerner open businesses such as restaurants, hotels, or handicraft shops are widely spread in the village of Senggigi, West Lombok. The westerner is the beginning of the formation of cultural diversity and create multicultural nuances that exist in Senggigi both in the neighborhood of coastal attractions, to the downtown neighborhood like Mataram. So do not be surprised if in a tourist area such as Senggigi village known as a tourist destination we will meet a number of foreign people who have different cultural backgrounds with their respective characters that reflect the cultural distinctiveness of where the individual came from. In Lombok, local people are on average high in their culture. So that the multicultural conditions that exist among foreign citizens with local communities is certainly able to generate psychic reactions in the form of cultural shock that is usually followed by the emergence of unpleasant things caused by cultural differences between those who are brought together in one place the same village Senggigi, West 
Lombok. Culture is an adhesive tool in a community (Tilaar, 2004: 82).

In essence this is what became one of the effective rides for people in socializing and interacting with different individuals of different cultures to get to know each other. However, it cannot simply apply to foreign nationals who just entered the early stages of life on the island of Lombok as a place of monitoring. Being in a new, unfamiliar environment exposes foreign citizens to a social-psychological problem they have to go through first as a process of adaptation to the place of monitoring, because of the multicultural atmosphere among the foreign citizens, as well as the socio-cultural conditions of the indigenous people of Lombok island turned out to cause culture shock that occurs due to unprepared individual immigrants who move from a culture of new cultural origin with all the differences that exist within it. The existence of differences in cultural background and character among western people with host individuals will certainly give rise to differences in some ways of life, such differences can potentially be cultural capital if it leads to unity (integration) or associative. However, the phenomenon of culture shock experienced by foreign citizens entering the early stages of life in new environments as a reaction to find these differences can also potentially be a source of chaos, such as reluctant to interact, negative prejudices, and doubts of intercultural interactions that are vulnerable to a stereotype bad imagery) to new cultures to ethnocentricism in foreign individuals by underestimating, disintegration or disasosiatif and lead to conflict if the process of socialization of cultural adaptation is not running smoothly.

\section{REVIEW OF LITERATURE}

A. Culture Shock

\section{Definition Culture Shock}

Culture shock is a term used to describe a person's circumstances and feelings in the face of different new socio-cultural conditions. The concept of culture shock was introduced by Oberg (1960) to describe the deep response of depression, frustration and disorientation experienced by people living in a different new cultural environment. While Furnham and Bochner (1970) say that "culture shock is when one does not recognize the social habits of a new culture then he can not display the behavior in accordance with the rules applicable in the new environment".

2.

Through the concept of culture shock introduced by Oberg (1960) which was later refined by Furnham and Bochner (1970) shows that culture shock occurs usually triggered by one or more of the following three causes:

a. Loss of cues or signs, marks he knows. Though cues are part of everyday life such as signs, movement of body parts (gestures), facial expressions or habits that can tell someone how best to act in certain situations. b. Disconnection of interpersonal communication at a conscious level that leads to frustration and anxiety. Language barriers are the obvious cause of this disorder.

c. The crisis of identity by going out of his area someone will re-evaluate the image of him (Dayakisni, 2012: 265).

Culture shock can occur in different environments of individuals who are migrating from one region to another within their own country (intra-national) and individuals who move to another country for long periods of time (Dayakisni, 2012: 266). Oberg further explained that these things are rightly triggered by anxiety arising from the loss of signs and symbols of social relationships that he has known familiarly in social interactions, such as clues in the form of words, gestures, facial expressions, habits, or norms that individuals acquire throughout the course of their lives since the individual is born (Mulyana, 2006: 175). When the immigrant enters a new foreign cultural environment, all or almost all of these clues become vague or even vanishing, which can be described as an individual fish like a fish coming out of water. Although the individual is broad-minded and wellintentioned, the individual will still lose his grip, then the individual is frustrated by symptoms and reactions that are similarly suffered by an individual affected by a cultural shock. First of all the individual will reject the environment that causes discomfort to self regret. The home environment now feels so important. All the difficulties and problems faced become pressure and only the pleasant things in the yard are remembered to be sorely missed. For the nomadic individual only returns to his hometown which will bring him to reality.

3. Shock

Symptoms and Reactions Culture

In general, many early definitions focus culture shock as a syndrome, a raitive state of pathology or a specific deficit: the individual moves into a strange new environment, then develops a negative psychological phenomenon and some of the symptoms of this culture shock are urinating, drinking, eating and overeating; feelings of helplessness and the desire to continue to depend on the individual as one; angry / irritable because of trivia; exaggerated reactions to trivial diseases; until finally, the desire that peaked to return home (Mulyana, 2006: 175). Many cultural shocks cause emotional disturbances, such as depression and anxiety experienced by newcomers. In the early stages of new cultural adjustments, immigrant individuals will experience a period of oscillation between anger and depression. Cultural shock as a learning experience that includes acquisition and development of the skills, rules, and roles needed in a new culture setting. Cultural shock is also a loss of one's control as he interacts with others with different cultures. 
Loss of control generally does cause difficulty adjustment but is not always a psychological disorder (Mulyana, 2006: 176). Harry Triandis, a well-known psychologist, sees the cultural shock as a loss of one's control as he interacts with others from different cultures. Loss of control generally does cause difficulty adjustment but it is not always a psychological disorder (Shiraev and Levy, 2012: 443). Pedersen argues in one of the theories of culture shock to see this concussion as an early adjustment of new or foreign environments associated with individual development, education, and even personal growth. Briefly that all forms of mental and physical stress experienced by immigrant individuals while in a foreign location are referred to as a culture shock phenomenon, but the culture shock phenomenon that occurs in each individual has a different level or degree as to how far culture shock affects his life. There are several symptoms and reactions that are usually shown by individuals when experiencing culture shock can be seen from the following table:

TABLE I. SYMPTOMS AND CULTURE SHOCK REACTION

\begin{tabular}{|c|c|}
\hline $\begin{array}{l}\text { The Symptoms of } \\
\text { Culture Shock }\end{array}$ & $\begin{array}{l}\text { The Description Reaction of } \\
\text { Culture Shock }\end{array}$ \\
\hline $\begin{array}{l}\text { 1) Culture shock as } \\
\text { nostalgia. }\end{array}$ & $\begin{array}{l}\text { People feel homesick, } \\
\text { friends, and other familiar } \\
\text { experiences }\end{array}$ \\
\hline $\begin{array}{l}\text { 2) Culture Shock as } \\
\text { disorientation and loss of } \\
\text { control. }\end{array}$ & $\begin{array}{l}\text { The loss of familiarity about } \\
\text { the behavior of others. } \\
\text { Disorientation raises anxiety, } \\
\text { depression, and feeling } \\
\text { hopeless. }\end{array}$ \\
\hline $\begin{array}{l}\text { 3) Culture Shock as } \\
\text { dissatisfaction over } \\
\text { language barriers. }\end{array}$ & $\begin{array}{l}\text { Lack of communication or } \\
\text { difficult communication can } \\
\text { lead to frustration and } \\
\text { feelings of alienation. }\end{array}$ \\
\hline $\begin{array}{l}\text { 4) Culture Shock as a } \\
\text { loss of habit and } \\
\text { lifestyle. }\end{array}$ & $\begin{array}{l}\text { Individuals are not able to do } \\
\text { many activities that he } \\
\text { previously enjoyed: this } \\
\text { causes anxiety and feelings of } \\
\text { loss. }\end{array}$ \\
\hline $\begin{array}{l}\text { 5) Culture shock as the } \\
\text { assumption of } \\
\text { difference. }\end{array}$ & $\begin{array}{l}\text { The difference between a new } \\
\text { culture and a hometown } \\
\text { culture is usually exaggerated } \\
\text { and hard to accept }\end{array}$ \\
\hline $\begin{array}{l}\text { 6) Culture shock as a } \\
\text { perceived value } \\
\text { difference. }\end{array}$ & $\begin{array}{l}\text { This distinction is usually } \\
\text { exaggerated: new values } \\
\text { seem difficult to accept. }\end{array}$ \\
\hline
\end{tabular}

(Shiraev dan Levy, 2012: 444)

4. The Culture Shock phases of Samovar state that people usually pass through four levels of culture shock.
These four levels can be described in the shape of the $U$ curve, so it is called U-Curve.

a. The optimistic phase, the first phase described at the top left of the $U$ curve. This phase contains excitement, hopefulness, and euphoria in anticipation of the individual before entering a new culture.

b. Cultural problems, second phase in which problems with new environments begin to evolve, such as language difficulties, new traffic systems, new schools, and others. This phase is usually characterized by disappointment and dissatisfaction. This is a period of crisis in culture shock. People get confused and stunned by the surroundings, and can become frustrated and irritable, hostile, irritable, impatient, and even incompetent.

\section{Adaptation}

The westerner living in the village of Senggigi, West Lombok are indirectly required to be able to adjust to their environment. In the sociology dictionary explains some understanding of adaptation.

a)

\section{Adaptation}

1) The process of overcoming obstacles from the environment.

2) Utilizing limited resources for environmental and system purposes

3) Change process to adjust to changing situation

4) Adjustment of groups to the environment

5) Personal adjustment to the environment

6) Biological or cultural adjustment as a result of natural selection. 3

b) Adaptation, communal The process of adapting to the environment that occurs as an indirect result of organizing the population.

c) Adaptation, external Adjustment of social structure to social environment.

d) Adaptation, genetic Adjustment to the environment, as a result of genotype.

e) Adaptation, Individual Personal adjustment to the environment as a direct result of personal effort, and which is indirectly the result of organized population activity.

Adaptation, social The relationship between a group or institution with the physical environment that supports the existence of the group or institution (Soerjono Soekanto, 1985: 9). 
Ward and Kennedy in (Dakyakisni, 2012: 270) approach through two forms of adaptation. The first is, Sociocultural Adaptation, which shows the ability to negotiate interactions with members of the new host culture. Secondly, the psychological adaptation is influenced by the internal control center, some changes in life, contact with more fellow countrymen for social support, and lesser difficulty in the management of everyday social contacts. While sociocultural adaptation increases with the lower level of difference between host culture and immigrants, more interaction with host, extroversion and lower mood disturbance level.

\section{Socialization}

a) The definition of Socialization

Socialization by Peter Berger is a process whereby an individual learns to become a member who participates in society (Idianto, 2004: 115). According to David Goslin, socialization is a process of learning experienced by a person to gain knowledge, skills, values and norms in order for him to participate as a member in his community (Ihromi 1990: 30). Simply socialization can be defined as a lifelong process that deals with how the individual thinks of learning the ways of life, the social values that exist in a group so that he can adapt and be able to develop into an acceptable, functioning person within his group the. After understanding the understanding of socialization according to some experts above it can be concluded that socialization is a process traversed by every individual in learning about all the habits possessed by every human. The limitation of socialization is the process by which the individual studies the habitual attitudes, ideas, patterns of values and behavior in the society in which the individual lives.

b) The purpose of socialization

The main purpose of socialization is not merely so that rules and values are known and understood. The ultimate goal of socialization is for people to behave and act in accordance with the rules and values prevailing and for those concerned to appreciate it (Soerjono Soekanto, 1990: 442). Socialization as a social process has the following objectives:

1) Provide the skills and knowledge needed to live one's life in the midst of society where he becomes one of its members,

2) Adding the ability to communicate effectively and efficiently and develop the ability to read, write, and tell stories,
3) Assist the control of organic functions learned through proper self-discipline exercises,

4) Familiarize individuals with the basic values and beliefs that exist in the community (Idianto, 2004: 115).

\section{RESEARCH METHOdOLOGY}

In this case, the researcher uses a method that based on the purpose of this study.

\section{A. Research Design}

This research aims to know the factors and the reaction or the underlying symptoms of the occurrence culture shock as well as the impact it has on western people in Senggigi, West Lombok. This research applied a Qualitative research method that is observation, interview and document review.

\section{B. Source of Data}

The main sources of data in qualitative research are words, languages and actions, the rest is additional supporting data such as documents, photos and others (Moleong, 2007: 157). The actions of those who observed / interviewed are the main data sources recorded through written notes as well as via video recorder / audio tape.

\section{Data Collection}

1. Primary Data

This data is obtained through interviews with the subject or informants and direct observation in the field. Data or information is done by interview method. Related to this study, the data type is divided into words and action data source written. Researcher took data directly through observation and interviews with some western people in Senggigi West Lombok.

2. Secondary Data

The secondary data in this study comes from the source written, magazines, newspapers, journals, internet and research results relevant to the phenomenon of culture shock western people in Senggigi West Lombok.

\section{Data Analysis}

The data were analyzed through data reduction, data display and conclusion.

\section{RESEARCH FINDING AND DISCUSSION}

The Underlying Causes of Culture Shock Occurrence on Western people in Senggigi West Lombok. In this study, the concept of Western people in Senggigi West Lombok using the definition of Mochtar Naim, he mentioned wander is a special type of migration with its own cultural connotation that is an individual who comes from outside the region, leaving his hometown or homeland to travel to the city, region or even abroad, on their own, within a certain period of time / for a long period or not usually with the intention of returning 
home, and with the aim of continuing education to the college level. The reasons for their continuing study outside the region include expanding their horizons, gaining better education, gaining new experiences and expecting a better level of living (Mochtar Naim, 1984: 2).

Experience culture shock (this culture shock) is actually a natural thing experienced by individuals while being in the area with a new environment that is culturally different from the environment of origin. Aspects consisting of tension, feeling of loss, dislike of difference, feeling of helplessness away from the culture of origin, the confusion of role, feeling, identity, values held and not easily confuse or interact until the rejection of the social relations of the people who exist in a new environment, can cause individuals to feel depressed. Students living abroad who experience culture shock will feel the stage of anxiety about new things that he has never encountered so far, this is related to the ability to adapt to foreign environments, only the level of disturbance experienced by individuals is different from one individual to another individual, depending on how far the cause of culture shock can affect the individual self. Culture shock occurs usually triggered by one or more of the following three causes, namely:

Loss of cues or familiar signs. Though cues are part of everyday life such as signs, movement of body parts (gestures), facial expressions or habits that can tell a person how best to act in certain situations.

Disconnection of interpersonal communication both at the conscious level leading to frustration and anxiety. Barriers to language differences are an obvious cause of this disorder.

3) Crisis of identity by going out of his area someone will re-evaluate the image of him (Dayakisni, 2012: 265).

Based on the results of interviews with eight Western people in Senggigi West Lombok, then the researchers found the cause culture shock as well as the symptoms and culture shock reaction in the students overseas as follows:

\section{a) Internal Causes}

Psychologically demonstrating intra psychic ability to facing a new environment that is desired. It is in the will by internal control center (Dayakisni, 2012: 270). There is influence intrapersonal in the individual, including skills communicate, experience in cross-cultural settings, abilities socialize and characterize individual characters (tolerance or independence are away from the family as the important people in his life who play a role in support and supervision systems). As with the results interviews from western people from Germany who was 10 years living in Senggigi West Lombok as follows:

"... because the distance makes me feel I have lost people I've known before, sad to be in an environment I do not recognize, farther than the old man very tortured and often make me cry easily, even can get sick when no longer unstoppable sense of my longing. It now felt very much if it was far from the old man very heavy, the impact to make my mood messy, what's up so lazy, no one encouraging. When that taste start coming and unstoppable, I would prefer to be alone in my room kosku even to my appetite lost sometime also can get sick because unstoppable sense of my longing with home hometown especially with my family. Here nothing should take care of itself, when the pain must be smart to take care of themselves to go own treatment is very heartbreaking kak, all that makes me feel depressed because of distance. I feel alone here in this foreign place". (Heiner Werdeling, male informant from Germany on 25 December 2017 at 14.00 pm).

And interview results from Heidi Margaret Petch westerner from Australia that shows the internal cause forming culture shock is as follows:

"... in the beginning I feel so relaxed and I enjoyed everything, no doubt of course I am so nervous, not confident because it is located in a foreign place, feel there is no group of friends I used to be with. I feel lost identity while in this new environment. I never thought that this is would happened to me. Everything is just not as easy as I was thought. But I am lucky because I have one local friend here who always help me in everything" (Heidi Margaret Petch on December 22, 2017 at $16.00 \mathrm{pm})$.

From the results of the interviews that researchers have shown that intrapersonal influences in individuals, such as skills communicate, experience in cross-cultural settings, abilities socialize and characterize individual characters (tolerance or independence are away from the family as the important people in his life who play a role in support and oversight systems) is absolutely influential on the smalloccurrence cause of culture shock in the individual self. The researchers concluded that in general individuals who have not never do cross cultural experience and lack of information factual neighbors and location of the place of monitoring will be easier experience a cultural shock, which is because the individual is not enough ready to prepare strategy against all things about like cross-cultural understanding of her in the place of ranger as the new environment that can then spread to the problem widespread and more complex discomfort (mood).

\section{b) External Causes}

The existence of socio cultural variation that is related capability with the level of cultural differences that affect the high low transition between cultures of origin to new cultures (Dayakisni, 2012: 270). Concussion culture happens more quickly if the culture is getting different, this is it including social, cultural, customs, religion, climate, taste food, language, gestures / body expression until facial expression, way dress / lifestyle, technology, education, rules and norms social in society as well as differences in the behavior of the host population. As in the results of interviews from eight 
informants overseas students showing the external causes of the shaper culture shock is as follows:

\section{1) Patterns, types, flavors and meals}

One of the biggest differences between immigrants and masters a home that is usually a problem for immigrant individuals it is food. Pattern, type, taste and portion of a person's meal is closely related to the culture in which he lived and has attached to the individual self. Therefore, when individuals are in the host area with patterns, types, flavors and servings eat different, he will experience shock and frustration which leads to the occurrence of culture shock, "... Of course the thing that so difficult here is the food. I can't found any western taste here. I will only get it if I came to restaurants. Ah.. I miss my mom so much. Instead of restaurant, I sometimes go to junk food like KFC, and the other craps. Hahaha". (Daniella from Germany, 21 December 2017 at 16.00 pm).

\section{2) Customs}

The external causes of Culture shock are the differences of customs in Senggigi West Lombok,

"In Switzerland, if we met someone we just passing by and sometimes just a bit eye contact. But here so different, every time I meet somebody, I have to shake hand, hugging, and the other warm things. It's nice. But when I will hug a lady, they seems to be keep away from me. I didn't know if that is impolite". (Darren from Switzerland, 24 December 2017)

Refers to traditions that are commonly practiced by community in every area that notebene have characteristic cultures that are different from each other. And a manndemands for overseas individuals to be able to adapt with customs in his new area as a form appreciate in the host environment and how to be able to to blend in. But unfortunately, adapt to custom the new customs are not an easy thing for a person entrants, then individuals tend to nexperience shock culture especially in terms of then customs.

\section{CONCLUSION}

From the results of interviews that researchers have done on eight Western people in Senggigi West Lombok showing that the period of culture shock will be experienced by every western who choose to be stay longer in Senggigi West Lombok, it's just culture shock that happens at every individuals vary about the extent to which culture shock affects his life. In this study researchers agree with the opinion samovar that individuals will experience culture shock during the first week his arrival and will be resolved until the first year. New westerner has the chance to experience culture shock stage that is optimistic stage up to the stage of crisis culture and more advanced. An individual surviving culture shock sufferer who started interacting with new people around the new culture will encouraging self-directed analysis allowing individuals to discover new insights from within the psychic aspect of himself. This new structure will become more visible through emotional experiences while interacting with new cultures. In this, the experience of interaction with a new culture is not always negative, but instead will encourage individuals to recognize themselves in a way deeper in order to make himself more flexible to adjust to new culture. The process of discovering new meaning caused by new cultural influences will take place naturally and delivering individuals on adjustment to new environments. Experience shock culture is normal occurs in overseas students who started his life in a new area with situations and conditions socio-cultural environment that is different from the region of origin. Level success in dealing with culture shock problems is highly dependent with the effort and sincerity of each individual within uphold the original purpose of wandering. So based on the results of research on "The Phenomena of Culture Shock On Western People In Senggigi, West Lombok" can be concluded that the solution or solution of culture shock is good done by western people is to adapt, that is willing attitude accept and understand culture in Lombok, Indonesia.

\section{References}

Dayakisni, T. (2012). Psikologi lintas budaya. Malang : UMM Press.

Koentjaraningrat. (1980). Pengantar Ilmu Antropologi. Jakarta: Aksara Baru

Moleong. L. J. (2006). Metodologi penelitian kualitatif. Bandung: Remaja Rosdakarya

Milles, M. B. \& Huberman, A M. (1992). Analisis data kualitatif. Jakarta: Universitas Indonesia Press

Shiraev. Eric B, David A. Levy. (2012). Psikologi lintas kultural pemikiran kritis dan terapan modern (Edisi Keempat). Jakarta: Prenada Media Group

Spencer-Oatey, H. (2012). What is culture? A compilation of quotations. $\quad$ Retrieved from http://www.warwick.ac.uk/globalpadintercultural

Goebel, Z. (2013). The idea of ethnicity in Indonesia [Abstract]. Tilburg Papers in Culture Studies, 71, 1-34. 